ISSN 2338-5324 (print)

ISSN 2442-7276 (online)

Online di http://jkp.fkep.unpad.ac.id

DOI : $10.24198 / \mathrm{jkp}$

\title{
Foot Massage Modification to Reduce Blood Pressure in Pregnant Woman with Preeclampsia
}

\author{
Ermiati, Anita Setyawati, Etika Emaliyawati \\ Department of Maternity Nursing, Faculty of Nursing, Universitas Padjadjaran \\ Email: ermiati@unpad.ac.id
}

Submitted: 7-12-2017 Accepted: 24-7-2018 Published: 10-8-2018

\begin{abstract}
The Maternal Mortality Ratio (MMR) in Indonesia remains high, including in West Java province. One of the MMR causes is preeclampsia (24\%). Currently, the management of preeclampsia is focused on pharmacological therapy. Preeclampsia is characterized by high blood pressure. Some studies revealed that non-pharmacological therapy was effective in dealing high blood pressure including foot massage. Foot message has benefits both physiologically and psychologically. However limited study applied this massage among pregnant women with preeclamsia. The aim of this study was to determine the effectiveness of as a complementary therapy: foot massage to reduce of blood pressure among pregnant women with preeclampsia. The study applied quasi experimental design with time series approach. The samples were chosen using consecutive sampling technique. This study involved 30 pregnant women with preeclampsia. There were two steps of data collection. First, respondents' blood pressure was measured by researchers without any interventions for 6 days. Second, the 7th -12 th respondents had 20 minutes message, and observed blood pressure at the first minute before massage (pr-etest), and the 30th minutes after massage (post-test). Data were analyzed using Friedman Test. The result showed that there were no significant differences of mean systolic and diastolic blood pressure between pre-test and post-test $(p>0.05)$ in control period. Whereas, in the treatment period showed that there were a significant differences of mean systolic blood pressure between pre-test and post-test on the seventh day until twelfth day $(\mathrm{p}<0.05)$. While, the significantly differences in mean of diastolic blood pressure between pre-test and post-test were present during the eighth until twelfth in treatment period $(\mathrm{p}<0.05)$. This study revealed that there were significant differences in decreasing of blood pressure among pregnant women with preeclampsia after treatment by foot massage. The foot massage techniques can be used as one of the interventions to lower blood pressure in pregnant women with preeclampsia, however further research is needed to support the evidence based for nursing intervention especially in complementary therapies.
\end{abstract}

Keywords: Blood pressure, foot massage, preeclampsia, pregnant women. 
Ermiati: Foot Massage Modification to Reduce Blood Pressure in Pregnant Woman with Preeclampsia

\section{Introduction}

The world development framework has shifted from Millennium Development Goals (MDGs) to Sustainable Development Goals (SDGs) (World Health Organization, 2016). One of the SDGs goals is a good health, including reducing maternal mortality rate (MMR). MMR is the number of maternal deaths during pregnancy, childbirth, and childbirth caused by pregnancy, childbirth, after childbirth but not for other causes such as accidents, falls, etc. in every 100,000 live births (Ministry of Health of the Republic of Indonesia, 2011).

The SDGs' targeted that the MMR is below 70 per 100,000 live births by 2030 . While, the Indonesian Population Demographic Survey (2014) reported that MMR in Indonesia was 228 per 100,000 live births (West Java Provincial Health Office, 2015). In addition, the Routine Report of Maternal Health Program (LRPKI) reported that West Java was the highest rank in the number of MMR, 765 cases of 5.019 cases of maternal deaths occurred in West Java in 2013. It is known that $24 \%$ cause of maternal death in Indonesia is cased by preeclampsia (Suryanti, 2015).

Preeclampsia is a specific multisystemic disorder in pregnancy characterized by hypertension and proteinuria after 20 weeks gestation (Rahmadhayanti, Hayati, \& Saleh, 2014). Preeclampsia is needed to be treated appropriately because it would cause serious complications to mother and fetus including maternal complications and life-threatening fetal complications (Heazell, 2010). This would also impact mothers' and fetus quality of life.

Nowadays the therapy of preeclampsia focuses on conventional medical therapy and pharmacology. Those therapies are only affecting through physiological mechanisms. According to Nightingale's theory, human needs is holistic including physiological, psychological, social, and spiritual needs of both healthy and unhealthy. This holistic approach is illustrated by applying complementary therapies combined with the conventional medical therapy. One type of complementary therapies that have proven by literatures in reducing blood pressure through physiological, psychological, social, and spiritual mechanisms is foot massage (Setyoadi \& Kushariyadi, 2011).

The foot massage is a soft-tissue manipulation of the feet without any specific point that associated with other parts of the body (Coban \& Sirin, 2010). Several studies have proven the benefits of foot massage physiologically and psychologically (Puthusseril, 2006; Kozier, Erb, Berman, \& Snyder, 2010)

One physiological effect of foot massage is to reduce the blood pressure. Hayes and Cox's study showed that foot massage have reduced blood pressure, heart rates, and respiratory rates (Smith, Yamashita, Bryant, Hemphill, \& Kutner, 2009). In addition, foot massage also decreased Mean Arterial Pressure (MAP), heart rates, and respiratory rates and increased oxygen saturation (Kaur, Kaur, \& Bhardwaj, 2012; Setyawati et al., 2016). Another study found that the effect of foot massage was reducing pain, anxiety, depression, and other negative psychological perceptions that one of sign was low the blood pressure (Chacko, 2007; Halm, 2008).

Foot massage manipulation consists of 5 basic techniques: effleurage, petrissage, tapotement, friction, and vibration (Haakana, 2008). The foot massage was performed on the soles and back of the feet for 10 minutes (Wang, Tsai, Lee, Chang, \& Yang, 2008). Other studies foot massage performed on the soles and back of feets and legs for 20 minutes (Halm 2008; Kaur et al. 2012; Setyawati et al., 2016).

Many researchs has proven the effect of foot massage physiological and psychological, even though it applied in different points of feets and times. Study literatures showed that foot massage in different points of massage and and times effected different blood pressure in the treatment group (Falkensteiner, Mantovan, Müller, \& Them, 2011). However, there is no a study that assess the effectiveness of foot massage in pregnant women with preeclampsia. This study is aimed to determine the effectiveness 
Ermiati: Foot Massage Modification to Reduce Blood Pressure in Pregnant Woman with Preeclampsia

of a complementary therapy: foot massage to reduce of blood pressure among pregnant women with preeclampsia.

\section{Method}

Theresearch design was the quasi experimental with time series design. The population in this study were all pregnant women in the work area of Jatinangor Community Health Center $(\mathrm{CHC}=$ Puskesmas). The samples in this study were 30 pregnant women with preeclampsia in the PHC of Jatinangor. The samples were chosen using the consecutive sampling technique. The inclusion criteria were respondents who were diagnosed with preeclampsia, systolic blood pressure $>120$ $\mathrm{mmHg}$, diastolic blood pressure $>80 \mathrm{mmHg}$. The exclusion criteria were respondents with fractures, trauma, or leg injuries, and had venous thrombosis manifestations. The instrument of this study was an observation sheet including respondent's demographic data, clinical data, and blood pressure data of respondent: pretest and posttest. Researchers also provided the foot massage intervention protocol for respondents. Data were gathered using time series design, respondents had two roles as control and interventions group. First, as the control group, researchers observed respondents' blood pressure for 1-6 days, in the first minute (pretest) and 30th minutes (posttest). Second, the same respondent obtained foot massage for 20 minutes from day 7 to day 12, along with the blood pressure was observed in the first minutes (pretest) and the thirtieth minutes (posttest). The data were analysed using Friedman Test. Based on the normality test, it was found that blood pressure data in this study was not normally distributed.

\section{Result}

The univariate analysis applied to analyze the characteristics of respondents including

Table 1 Characteristic of respondents $(n=30)$

\begin{tabular}{llcc}
\hline \multicolumn{1}{c}{ Characteristic of Respondents } & f & \% \\
\hline Age & No risk & 20 & 66.7 \\
\multirow{3}{*}{ Work Status } & Have a risk & 10 & 33.3 \\
\multirow{5}{*}{ Education } & Housewife & 24 & 80 \\
& Private employee & 6 & 20 \\
& College & 1 & 3.3 \\
& High school & 16 & 53.3 \\
\multirow{3}{*}{ Pregnancy Age } & Junior school & 12 & 40 \\
& Elementary & 1 & 3.3 \\
Pregnancy Status & Trimester 2 & 16 & 53.3 \\
& Trimester 3 & 14 & 46.7 \\
Grand Multigravida & Primipara & 6 & 20 \\
& Multipara & 24 & 80 \\
& Yes & 2 & 6.67 \\
& No & 28 & 93.3 \\
\hline
\end{tabular}


Ermiati: Foot Massage Modification to Reduce Blood Pressure in Pregnant Woman with Preeclampsia

Table 2 The mean distribution of respondents' blood pressure between Pre-Posttest on the control and intervention group

\begin{tabular}{|c|c|c|c|c|c|c|c|c|c|c|c|c|c|}
\hline \multirow[t]{2}{*}{$\mathrm{TD}^{8}$} & \multirow[t]{2}{*}{ Observation } & \multicolumn{6}{|c|}{ Control } & \multicolumn{6}{|c|}{ Treatment } \\
\hline & & 1 & 2 & 3 & 4 & 5 & 6 & 1 & 2 & 3 & 4 & 5 & 6 \\
\hline \multirow[t]{4}{*}{ TDS } & $\begin{array}{l}\text { Pretest } \\
\text { (average } \\
\pm \mathrm{SD})\end{array}$ & $\begin{array}{l}127,23 \\
\pm 9,504\end{array}$ & $\begin{array}{l}126,40 \\
\pm 8,585\end{array}$ & $\begin{array}{l}122,90 \\
\pm 8,980\end{array}$ & $\begin{array}{l}121,60 \\
\pm 8,669\end{array}$ & $\begin{array}{l}124,53 \\
\pm 8,549\end{array}$ & $\begin{array}{c}126,27 \\
\pm 12,114\end{array}$ & $\begin{array}{l}125,30 \\
\pm 9,685\end{array}$ & $\begin{array}{l}125,37 \\
\pm 8,282\end{array}$ & $\begin{array}{l}123,67 \\
\pm 9,672\end{array}$ & $\begin{array}{r}125,87 \\
\pm 11,203\end{array}$ & $\begin{array}{l}124,83 \\
\pm 9,079\end{array}$ & $\begin{array}{c}121,10 \\
\pm 10,186\end{array}$ \\
\hline & $\begin{array}{l}\text { Posttest } \\
\text { (average } \\
\pm \mathrm{SD} \text { ) }\end{array}$ & $\begin{array}{c}124,37 \\
\pm 10,287\end{array}$ & $\begin{array}{l}124,60 \\
\pm 7,863\end{array}$ & $\begin{array}{l}122,93 \\
\pm 9,606\end{array}$ & $\begin{array}{l}123,57 \\
\pm 9,054\end{array}$ & $\begin{array}{l}122,27 \\
\pm 9,784\end{array}$ & $\begin{array}{l}124,07 \\
\pm 7,939\end{array}$ & $\begin{array}{l}119,40 \\
\pm 9,561\end{array}$ & $\begin{array}{r}118,53 \\
\pm 8,764\end{array}$ & $\begin{array}{l}116,57 \\
\pm 9,623\end{array}$ & $\begin{array}{l}119,57 \\
\pm 9,533\end{array}$ & $\begin{array}{l}116,93 \\
\pm 7,723\end{array}$ & $\begin{array}{r}113,83 \\
\pm 10,613\end{array}$ \\
\hline & Z & $-2,593$ & $-1,419$ & $-0,141$ & $-2,150$ & $-2,831$ & $-1,223$ & $-3,395$ & $-4,649$ & $-4,297$ & $-4,610$ & $-4,610$ & $-4,459$ \\
\hline & $\mathrm{p}$ & 0,010 & 0,156 & 0,888 & 0,032 & 0,005 & 0,221 & 0,001 & 0,000 & 0,000 & 0,000 & 0,000 & 0,000 \\
\hline \multirow[t]{4}{*}{ TDD } & $\begin{array}{l}\text { Pretest } \\
\text { (average } \\
\pm \mathrm{SD})\end{array}$ & $\begin{array}{c}81,17 \\
\pm 8,107\end{array}$ & $\begin{array}{c}79,80 \\
\pm 8,880\end{array}$ & $\begin{array}{c}79,60 \\
\pm 8,720\end{array}$ & $\begin{array}{c}79,30 \\
\pm 8,035\end{array}$ & $\begin{array}{c}80,53 \\
\pm 9,442\end{array}$ & $\begin{array}{r}79,50 \\
\pm 8,291\end{array}$ & $\begin{array}{c}78,37 \\
\pm 10,473\end{array}$ & $\begin{array}{c}80,20 \\
\pm 7,814\end{array}$ & $\begin{array}{c}79,10 \\
\pm 8,515\end{array}$ & $\begin{array}{c}79,93 \\
\pm 9,552\end{array}$ & $\begin{array}{c}79,70 \\
\pm 9,086\end{array}$ & $\begin{array}{c}78,47 \\
\pm 8,565\end{array}$ \\
\hline & $\begin{array}{l}\text { Posttest } \\
\text { (average } \\
\pm \mathrm{SD})\end{array}$ & $\begin{array}{c}80,50 \\
\pm 8,341\end{array}$ & $\begin{array}{c}80,53 \\
\pm 7,838\end{array}$ & $\begin{array}{c}80,07 \\
\pm 7,714\end{array}$ & $\begin{array}{c}79,33 \\
\pm 8,001\end{array}$ & $\begin{array}{c}79,83 \\
\pm 8,502\end{array}$ & $\begin{array}{c}80,80 \\
\pm 5,857\end{array}$ & $\begin{array}{c}77,63 \\
\pm 8,455\end{array}$ & $\begin{array}{c}75,80 \\
\pm 8,973\end{array}$ & $\begin{array}{c}76,43 \\
\pm 8,561\end{array}$ & $\begin{array}{c}76,50 \\
\pm 8,496\end{array}$ & $\begin{array}{c}75,97 \\
\pm 7,449\end{array}$ & $\begin{array}{c}75,33 \\
\pm 8,568\end{array}$ \\
\hline & Z & $-1,160$ & $-0,069$ & $-0,433$ & $-0,096$ & $-1,088$ & $-0,523$ & $-0,743$ & $-3,817$ & $-3,117$ & $-3,825$ & $-3,773$ & $-2,980$ \\
\hline & $\mathrm{p}$ & 0,246 & 0,945 & 0,665 & 0,923 & 0,277 & 0,601 & 0,458 & 0,000 & 0,002 & 0,000 & 0,000 & 0,003 \\
\hline
\end{tabular}

of age, occupation, education, gestational age, and pregnancy status (primipara or multipara). Frequency distribution of respondents' characteristics present in table 1.

Table 1 revealed that the majority of respondents' age were not at a risk for pregnancy $(66,7 \%)$, they were a housewife $(80 \%)$, attended high school $(53,3 \%)$, trimester two $(53.3 \%)$, multiparas $(80 \%)$, and only two of them were grand multigravida.

Table 2 presented that the mean difference of systolic blood pressure between pretest and posttest were significant. The first treatment period $(\mathrm{p}=0.001)$, second day $(\mathrm{p}=0.000)$, third day $(p=0.000)$, fourth day $(p=0.000)$, fifth day $(\mathrm{p}=0.000)$, and the sixth day $(\mathrm{p}$ $=0.000)$. The same trend also found in the diastolic blood pressure. The mean differences between pretest and posttest were the second day of treatment $(\mathrm{p}=0.000)$, third day $(\mathrm{p}=$ $0.002)$, fourth day $(\mathrm{p}=0.000)$, fifth day ( $\mathrm{p}$ $=0.000)$, and day sixth $(\mathrm{p}=0.003)$. Table 2 . The mean distribution of respondents' blood pressure between Pre-Posttest on the control and intervention group

\section{Discussion}

The characteristics of pregnant women in this study were multiparous, aged 20 to 35 years, and only two women were grand multigravida. Respondents in this study have no risk factors of preeclampsia. Preeclampsia is a specific condition of pregnancy characterized by hypertension after the 20th week of pregnancy, and women had history of normal blood pressure (Bobak et al., 2004; Lewis, 2015).

Signs and symptoms of preeclampsia arised during pregnancy and disappeared after giving birth. No particular criteria for whom would suffer from preeclampsia. There were risk factors associated with preeclampsia including primiparas, grandmultigravids, large fetuses, multiple pregnancies, obesity, and maternal age less than 20 years or more than 35 years (at risk). Respondents in this study excluded those risks, in fact they suffered of preeclampsia. Health workers should detect preeclampsia immediately whether pregnant women in risk or no risk conditions. 
Ermiati: Foot Massage Modification to Reduce Blood Pressure in Pregnant Woman with Preeclampsia

\section{The effect of foot massage to the blood pressure of pregnant women with preeclampsia}

The results of this study indicated that during the control period (no foot massage), respondents blood pressure did not decrease significantly. After foot massage the mean of systole and diastole of pregnant women's blood pressure decreased significantly both pretest and posttest. Physiologically, foot massage is part of cutaneous stimulation that would help the body to achieve homeostasis through arrangement of the extrinsic and intrinsic of peripheral blood flow. In extrinsic setting, smooth and rhythmic vibrations of muscles because of foot massage manipulation impacted vasomotor activities in the medulla (Guyton \& Hall, 2007; Marley, 2005; Price \& Wilson, 2005). Vasomotor activities mean releasing acetylcholine and histamine that impact relaxation of muscles and vasodilatation of arterioles (Marley, 2005). As a result, decreasing peripheral resistance, increasing the blood flow through the microvascular circulation section, and decreasing in the blood pressure.

The intrinsic processes, when blood flow have increased via microvascular circulation, it would stimulate secondary mechanisms that impacted arteries dilatation (Guyton \& Hall, 2007). Endothelial cells lining arterioles and small arteries synthesize would affect the level of contraction of artery walls. These ingredients are vasodilator substances called endellomial relaxation factors, which essentially consist of nitric oxide that a halflife in the blood for only 6 seconds. Healthy blood flow via arteries would cause "shearstress" in endothelial cells due to the viscous pull of blood to the vascular walls. This stress would change the shape of endothelial cells and increase the release of nitric oxide. The nitric oxide would be impacted relaxation and dilatation arterial walls. This is a beneficial mechanism because the dimensions of large blood vessels increased secondary, when the microvascular flow is increased.

The foot massage stimulates parasympathetic nerve fibers (Eimani \& Eshq, 2004). One of the function of these parasympathetic fibers is innervating sinoatrial and arterioventricular nodes (Hudak \& Gallo, 2010). Parasympathetic stimulation releases acetylcholine near nodal cells and decreases depolarization frequency, as a result decreasing heart frequency and rates. Decreasing heart rate impacted ventricular filling times are longer than usual, resulting in larger stroke volume and lead to the increase of cardiac output (Marley, 2005). A good cardiac output would improve blood circulation throughout the body including to the uteroplacental-fetal system. The extrinsic and intrinsic processes of peripheral blood flow, the foot massage would reduce the blood pressure of pregnant women with preeclampsia.

Several studies have proven the effect of foot massage on blood pressure of cancer patients and postoperative patients. Quattrin et al.'s (2006) study showed a significant decrease in systolic blood pressure $(\mathrm{p}<0.001)$ and a significant decrease in diastolic blood pressure $(p<0.05)$ in cancer patients with chemotherapy after foot massage. In addition, Chacko's (2007) also found a significant reduction in blood pressure in post-surgical abdominal patients after foot massage ( $p$ $<0.05)$.

Foot massage is a systematic and rhythmic touch using manipulation of whole areas of soft tissues in the feets. Foot massage has been done for thousands years with various techniques worldwide, including Egypt, India, and China. This massage has also become popular in some developed countries such as USA, UK, and Japan (Fan, 2006). According to the Oxford Concise Medical Dictionary, the basic this complementary therapy is that the feet have points that are related to other parts of the body. So if there is manipulation of soft tissue, for example the soft tissue of the foot, it would be affected in health improvement.

Foot massage is an easy and powerful element (Puthusseril, 2006). Physically, foot massage would be impacted relaxing muscles, relieving pain and congestion by releasing lactic acid, improving blood flow and lymph, and stretching joints. Foot massage is also considered to release the body's toxins and 
Ermiati: Foot Massage Modification to Reduce Blood Pressure in Pregnant Woman with Preeclampsia

stimulate the immune system. In the mentalemotional area, foot massage would relieve anxiety and provide a sense of relaxed wellbeing.

Several studies have demonstrated foot massage to decreased perception of pain in post-surgery patients in general, extensively (Wang \& Keck, 2004), in post-surgical abdominal patients (Chacko, 2007), and in post-cesarean section patients (Degirmen, Ozerdogan, Sayiner, Kosgeroglu, \& Ayranci, 2010). Foot massage has also been found to have an effect on the reduction of lower limb edema in pregnancy (Coban \& Sirin, 2010), decreased anxiety and depression in palliative care (Puthusseril, 2006), decreased agitation in dementia patients (Moyle, Johnston, \& O'Dwyer, 2011 ), as well as decreased pain, depression, anxiety, stress, and weakness in cancer patients (Cassileth \& Vickers, 2004; Quattrin et al., 2006; Falkensteiner et al., 2011; Kim \& Oh, 2011). This study finding in line with Hayes and Cox'x's study found that a significant reduction of Mean Arterial Pressure (MAP) of 25 patients at Intensive Care Unit (ICU) after foot massage (Smith et al., 2009). In addition, Eimani and Eshq's (2004) also found a a significant decrease of MAP $(p<0.001)$ after foot massage of 46 stroke patients who hospitalised in ICU. Futhermore, Shaban, Amiry, Mehran, and Kahrary's (2004) study showed a significant decrease of MAP after foot massage in 50 patients at the General Intensive Care Unit (GICU).

\section{Conclusion}

There was no difference in the mean of systolic and diastolic blood pressure both pretest and posttest $(p>0.05)$ in the control period from day 1 to day 6 . It was different with the intervention period, there was a significant difference in the mean of systolic blood pressure between pretest and posttest on day 7 to day $12(\mathrm{p}<0.05)$. In addition, the mean of diastolic blood pressure was significantly difference at the 8th day of treatment until the 12th day $(p<0.05)$ for pre and post test. This study has proven there is a significant difference in decreasing blood pressure in pregnant women with preeclampsia after foot massage.

This study has proven there is a significant difference in decreasing blood pressure of pregnant women with pre-eclampsia after foot massage. Foot massage techniques can be used as one of the interventions to reduce blood pressure in pregnant women with pre eclampsia. However, there is a need of further development of this intervention, so that it can be a useful nurses' intervention and evidence as a companion intervention for pharmacology therapy.

\section{References}

Bobak, I.M., Lowdermilk, D.L., \& Jensen, M.D. (2004). Maternity nursing. San Francisco: Mosby-Year Book.

Cassileth, B.R., \& Vickers, A.J. (2004). Massage therapy for symptom control: Outcome study at a major cancer center. Journal of Pain and Symptom Management, 28(3), 244-9. https://doi.org/10.1016/j. jpainsymman.2003.12.016.

Chacko, L. (2007). Impact of foot massage on the level of pain, heart rate and blood pressure among patient with abdominal surgery in a selected hospital at Mangalore. Rajiv Gandhi University of Health Science. Retrieved from http://119.82.96.198:8080/ jspui/bitstream/123456789/2241/1/Laly Chacko.pdf.

Coban, A., \& Sirin, A. (2010). Effect of foot massage to decrease physiological lower leg oedema in late pregnancy: A randomized controlled trial in Turkey. International Journal of Nursing Practice, 16(5), 454-60. $\quad$ https://doi.org/10.1111/j.1440172X.2010.01869.x.

Degirmen, N., Ozerdogan, N., Sayiner, D., Kosgeroglu, N., \& Ayranci, U. (2010). Effectiveness of foot and hand massage in postcesarean pain control in a group of Turkish Pregnant Women. Applied Nursing Research, 23(3), 153-158. Retrieved from http://www.sciencedirect.com/science/ article/pii/S0897189708000815. 
Ermiati: Foot Massage Modification to Reduce Blood Pressure in Pregnant Woman with Preeclampsia

Dinas Kesehatan Provinsi Jawa Barat. (2015). Angka kematian ibu. Retrieved from www. diskes.jabarprov.go.id

Eimani, E., \& Eshq, Z.M. (2004). The effects of foot massage on physiologic indicators in critically ill patients. Iranian Journal of Pharmaceutical Research, 3(2), 36.

Falkensteiner, M., Mantovan, F., Müller, I., \& Them, C. (2011). The use of massage therapy for reducing pain, anxiety, and depression in oncological palliative care patients: A narrative review.ISRNNursing, 2011, 929868. https://doi.org/10.5402/2011/929868.

Fan, K.W. (2006). Foot massage in Chinese medical history. Journal of Alternative and Complementary Medicine (New York, N.Y.), 12(1), 1-3. https://doi.org/10.1089/ acm.2006.12.1.

Guyton, A.C., \& Hall, J.E. (2007). Text book of medical physiology. Amsterdam: Elsevier.

Haakana, P. (2008). The acute effects of massage on muscle tone piia haakana. University of Jyvaskyla. Retrieved from https://jyx.jyu.fi/dspace/bitstream/ handle/123456789/19902/CL Haakana. pdf? sequence $=1$.

Halm, B.M.A. (2008). Essential oils for management of symptoms in critically ill patients. American Journal of Critical Care, $17(2), 160-164$.

Hudak, C.M., \& Gallo, B.M. (2010). Keperawatan kritis pendekatan holistik. (M. Ester, Ed.) (6th ed.). Terjemahan oleh Allenidekania, Betty Susanto, Teresa, Yasmin Asih. Jakarta: EGC.

Kaur, J., Kaur, S., \& Bhardwaj, N. (2012). Effect of "Foot Massage and Reflexology" on physiological parameters of critically ill patients. Nursing And Midwifery Research Journal, 8(3), 223-233.

Kementerian Kesehatan Republik Indonesia. (2011). Jaminan persalinan, upaya terobosan Kementerian Kesehatan dalam percepatan pencapaian target MDGs. Retrieved from http://www.kesehatanibu.depkes.go.id/ archives/99.

Kim, M.Y., \& Oh, P.-J. (2011). Meta-Analysis of the effectiveness on foot-reflexo-massage for cancer patients. Journal of Korean Oncology Nursing, 11(2), 127. https://doi. org/10.5388/jkon.2011.11.2.127.

Kozier, B., Erb, G., Berman, A., \& Snyder, S.J. (2010). Fundamentals of nursing. Frenchs Forest: Pearson.

Lewis, L. (2015). Fundamentals of midwifery. (L. Lewis, Ed.). Chichester: Wiley-Blackwell.

Marley, B. (2005). Massage physiology: Research, effects, indications, contraindications, and endangerment sites. In Benefits, Contraindications, Screening, Technique, and Special Considerations for the Massage Practitioner (pp. 81-105). Retrieved from www.elsevierhealth.com/ media/us/.../Chapter 05.pdf

Moyle, W., Johnston, A.N.B., \& O'Dwyer, S.T. (2011). Exploring the effect of foot massage on agitated behaviours in olderpeople with dementia: A pilot study. Australasian Journal On Ageing, 30(3), 159-61. https:// doi.org/10.1111/j.1741-6612.2010.00504.x.

Price, S.A., \& Wilson, L.M. (2005). Patofisiologi: Konsep klinis proses-proses penyakit. (H. Hartanto, Ed.) (6th ed.). Terjemahan Oleh Brahm U. Pendit. Jakarta: EGC.

Puthusseril, V. (2006). "Special Foot Massage" as a complimentary therapy in palliative car. Indian J Palliative Care, 12(2), 71-77.

Quattrin, R., Zanini, A., Buchini, S., Turello, D., Annunziata, M.A., Vidotti, C., ..., Brusaferro, S. (2006). Use of reflexology foot massage to reduce anxiety in hospitalized cancer patients in chemotherapy treatment: Methodology and outcomes. Journal Of Nursing Management, 14(2), 96-105. https:// doi.org/10.1111/j.1365-2934.2006.00557.x.

Rahmadhayanti, E., Hayati, L., \& Saleh, M.I. 
Ermiati: Foot Massage Modification to Reduce Blood Pressure in Pregnant Woman with Preeclampsia

(2014). Hubungan polimorfisme gen reseptor angiotensin II tipe $11166 \mathrm{~A} / \mathrm{C}$ dengan kejadian preeklampsia. Majalah Kedokteran Sriwijaya, 46(1), 52-58. Retrieved from http://ejournal.unsri.ac.id/index.php/mks/ article/view/2682.

Setyawati, A., Ibrahim, K., \& Mulyati, T. (2016). Pengaruh foot massage terhadap parameter hemodinamik non invasif pada pasien di General Intensive Care Unit. Jurnal Keperawatan Padjadjaran, 4(3), 283-292.

Setyoadi, \& Kushariyadi. (2011). Terapi modalitas keperawatan pada klien psikogeriatrik. Jakarta: Salemba Medika.

Shaban, Amiry, Mehran, \& Kahrary. (2004). Evaluation of immediate effect of foot massage on patient's vital signs in A General Intensive Care Unit. 9(20), 87. Retrieved from http://web.ebscohost.com/ehost/ detail? $\mathrm{vid}=6 \& \mathrm{sid}=242 \mathrm{db} 384-\mathrm{fb} 40-494 \mathrm{e}-$ 9417-3a36cb4d7ea6\%40sessionmgr104\&hid $=114 \&$ bdata $=$ JnNpdGU9ZWhvc3QtbGl2ZQ $\% 3 \mathrm{D} \% 3 \mathrm{D} \# \mathrm{db}=\mathrm{rzh} \& \mathrm{AN}=2005090573$.
Smith, M.C., Yamashita, T.E., Bryant, L.L., Hemphill, L., \& Kutner, S. (2009). Providing massage therapy for people with advanced cancer: What to expect. The Journal of Alternative and Complementary Medicine., 13(6), 739-744.

Suryanti, P. E. (2015). Hubungan preeklampsia dengan kejadian asfiksia pada bayi baru lahir di RSUP Sanglah Denpasar. Universitas Sebelas Maret.

Wang, H.-L., \& Keck, J.F. (2004). Foot and hand massage as an intervention for postoperative pain. Pain Management Nursing, 5(2), 59-65. Retrieved from http:// www.sciencedirect.com/science/article/pii/ S1524904204000037.

Wang, M.-Y., Tsai, P.-S., Lee, P.-H., Chang, W.-Y., \& Yang, C.-M. (2008). The efficacy of reflexology: Systematic review. Journal of Advanced Nursing, 62(5), 512-20. https:// doi.org/10.1111/j.1365-2648.2008.04606.x.

World Health Organization. (2016). Sustainable development goals. Retrieved from www.who.int. 